\title{
Effects of Topical Capsaicin on Cutaneous Innervation: Implications for Pain Management
}

\author{
Keith Bley*
}

Solimar Therapeutics, Inc, 1134 Crane Street, Suite 216, Menlo Park, CA 94025, USA

\begin{abstract}
Changes in cutaneous innervation are a hallmark of neuropathic pain syndromes. Although in few cases the density of cutaneous innervation increases in painful areas, for the most part the density of nociceptive sensory nerve endings decreases and the degree of deinnervation seems to correlate with the severity of pain. In combination with tests for nociceptor function, immunostaining for protein gene product 9.5 (PGP 9.5) is commonly used as diagnostic tool to indicate these pathophysiological changes in cutaneous innervation. However, sole reliance on PGP 9.5 may underestimate the presence of regenerating sensory nerve terminals or fail to capture changes in the expression of proteins such as ion channels or receptors. Topical capsaicin consistently reduces intra-epidermal nerve fiber density assayed via PGP 9.5, and also increases thresholds for activation of some thermoreceptors. The mechanism of action involves a highly localized insult to cutaneous nociceptors mediated by activation of TRPV1 and calcium overload, and perhaps even a direct toxicity to mitochondria. It is possible that topical capsaicin and lidocaine share an ability to reduce cutaneous innervation by inducing localized toxicity in mitochondria-rich nociceptive terminals. Overall, the high local concentrations of drugs and even excipients delivered by topical analgesics into the skin may be able to activate secondary pharmacodynamic processes. Optimizing topical formulations of capsaicin or other analgesics to maximize pain relief with the fewest adverse effects is not a simple matter of varying drug concentration, and it is highly questionable whether 'bioequivalence' could ever be based simply upon equivalent cutaneous drug delivery.
\end{abstract}

Keywords: Capsaicin, nociceptor, pain, PGP 9.5, lidocaine, TRPV1.

\section{INTRODUCTION}

Capsaicin has a long history of human use as a food additive and medicine, and has been the subject of thousands of research papers. The first formal report of the painreducing properties of topical capsaicin appeared in 1850 as a recommendation to use an alcoholic hot pepper extract on burning or itching extremities [1]. Creams, lotions and patches containing capsaicin, generally in the range of 0.025 to $0.1 \%$ by weight, are now available in many countries, often without the requirement of a prescription, for the management of neuropathic and musculoskeletal pain. Clinical studies involving three to five topical skin applications per day for periods of 2 to 6 weeks have generally suggested modest benefits against various pain syndromes, including osteoarthritis, postherpetic neuralgia, and painful diabetic neuropathy $[2,3]$. With the recent FDA and EMA approvals of Qutenza ${ }^{\mathbb{B}}$, a single-use highconcentration topical capsaicin formulation for the management of peripheral neuropathic pain, substantially more formal data on this drug substance is now available.

Capsaicin and its topical delivery have frequently been reviewed $[$ e.g., 4, 5]. This article addresses some of the knowledge gaps which have yet to be addressed in previous literature, and summarizes some of the key data pointing to

\footnotetext{
*Address correspondence to this author at the Solimar Therapeutics, Inc, 1134 Crane Street, Suite 216, Menlo Park, CA 94025, USA; Tel: 650-861-0388; E-mail: kbley@solimarthera.com
}

potential indications for topical capsaicin. First, is an examination of the ways that innervation of the skin - the site of action - have been studied and a survey of extensive literature on changes in cutaneous innervation. Attention is then turned to the effects of capsaicin, its dominant mechanism of action and the possibility that a contribution from secondary pharmacological mechanisms cannot be excluded. It will be suggested that capsaicin may have shared mechanisms of action with another topical analgesic. Finally, the limitations of focusing merely on capsaicin concentrations and not the delivery rate and other potentially neurotoxic components of topical formulations are discussed.

\section{CHANGES IN CUTANEOUS INNERVATION WITH PAIN SYNDROMES AND CAPSAICIN EXPOSURES}

The somatosensory nervous system undergoes integrated responses and adaptations to a wide variety of traumas, diseases and metabolic or iatrogenic insults. The most peripheral aspects of the sensory nervous system may display the most substantial changes, as sensory nerve fibers and terminals in the epidermis and dermis are both highly vulnerable to superficial trauma and completely reliant upon the health and integrity of their supportive cell bodies and proximal axons. Because intact cutaneous innervation is dependent upon so many factors, innervation of the skin is somewhat heterogeneous in healthy young adults and becomes progressively more heterogeneous with aging due to cumulative environmental and internal factors [6]. 
Changes in innervation of the epidermis and dermis by sensory nerve fibers can be quantified by two functional assays: quantitative sensory testing (QST) and laser-evoked potentials (LEPs). QST involves analysis of responses to stimuli of controlled intensity. Responses to thermal stimuli can be quantified by applying probes which are rapidly heated or cooled and activate cutaneous thermoreceptors [7]. Mechanical sensitivity to tactile stimuli can be measured by using von Frey hairs or monofilaments, pricking with pins and electronic vibrometers. LEPs are measurements of cortical responses using lasers to selectively stimulate various thermoceptors [8]. Lasers can emit radiant-heat pulses which - in some protocols - selectively activate the two classes of cutaneous nociceptors (A $\delta$ - and C-fiber nerve endings). When performed by skilled operators, QST and LEP exams have high sensitivity and are very reliable in assessing damage to both peripheral and central nervous systems. However, both QST- and LEP-based examinations are time consuming and rely upon on expensive equipment. Moreover - especially for QST - training of the operator (and even the subjects) and highly consistent techniques are critical to obtaining reliable and highly reproducible data [9]. Therefore, QST and LEP are not best suited for quantitative comparison of cutaneous innervation data across studies.

A method much less reliant on the clinical skill of the operator and thus more suitable for data pooling across laboratories involves quantification of cutaneous innervation via skin punch biopsies (often $3 \mathrm{~mm}$ in diameter). Skin punch biopsies constitute a relatively easy procedure and are minimally invasive [10]. Tissue samples are first preserved and then stained for various antigens present in the cutaneous nociceptors. The most commonly used antibody is to protein gene product 9.5 (PGP 9.5), which is also known as ubiquitin carboxyl terminal hydrolase-1 [11]. Using counting rules that measure the number of nerve fibers which cross the dermal-epidermal junction, the density of intra-epidermal nerve fibers (IENFs) is obtained [12]. As it is widely assumed that all nerve fibers present in the epidermis are nociceptors (C- and some A $\delta$-fibers), IENF density is thought to be reflective of nociceptor innervation. Although initially available in only a few research centers, 3-mm punch biopsies for PGP 9.5 analysis are now much more widely available and can be ordered by many physicians as a diagnostic tool. Accordingly, substantially more data on cutaneous innervation is available from punch biopsies than from functional evaluations.

There are several important limitations to information gleaned from PGP 9.5 immunostaining, the first of which relates to the surprisingly wide distribution of the protein. Although PGP 9.5 expression in normal tissues was originally felt to be a structural component present in mature nerve fibers, strictly confined to neurons and neuroendocrine cells, PGP 9.5 has been subsequently reported in distal renal tubular epithelium, spermatogonia, Leydig cells, oocytes, melanocytes, prostatic secretory epithelium, ejaculatory duct cells, epididymis, mammary epithelial cells, Merkel cells and dermal fibroblasts [13]. Fortunately, few of these nonneuronal cell types found in the epidermis and thus are unlikely to diminish the reliability of IENF density analyses. However, intra-observer variability may be caused by differences in counting rules or their interpretation, or a basement membrane that is poorly visualized [14]. Another limitation for the study of changes in cutaneous innervation with diseases or trauma follows from the nature of PGP 9.5, which is a 'housekeeping' or structural protein present in mature nerve terminals. Several reports show that PGP 9.5 may be absent from growing nerve fibers that can be visualized by other markers. For instance, several studies have shown that regenerating nerve fibers may express antigens like growth-associated protein 43 (GAP-43) before PGP 9.5 [15]. In a study of the time-course of recovery of LEPs following topical capsaicin treatment, functional recovery occurred before PGP 9.5 immunostaining occurred, but fibers marked by GAP-43 did show a good correlation with the functional responses [16]. Another recent study further points to the complexity of the relationship between these two markers, as the correlation between PGP 9.5 and GAP-43 expression was diminished in diabetic patients relative to normal controls [17]. Finally, perhaps the most problematic limitation of PGP 9.5 analyses was introduced above: cutaneous innervation is somewhat heterogeneous in healthy young people, becomes more heterogeneous with age, and significantly more heterogeneous with metabolic disease or damage to the sensory nervous system. Therefore, the prognostic value (the 'signal-to-noise ratio') may be limited when based on a single 3-mm punch biopsy taken from a large area of painful involvement.

Even with all of these limitations, the best poolable information available about changes in cutaneous innervation relies upon data generated with PGP 9.5. Using this antigen, alterations of IENF density has been observed in many types of neuropathic pain and other syndromes or diseases. Table 1 shows the correlations between peripheral neuropathies, diseases and other disorders and changes in PGP 9.5 immunostaining. The degree of IENF reductions appears to correlate with the severity of pains or disorders. As has been articulated elsewhere [5, 18, 19], it is the hyperactivity or hypersensitivity of residual cutaneous nociceptors that is thought to provide the sensory barrages that drive many chronic pain syndromes.

Administration of topical capsaicin causes a reduction in cutaneous nociceptor function and innervation. Many immunohistochemical studies using antibodies to PGP 9.5 or other nerve fiber proteins provide evidence that capsaicin can produce highly localized loss of nociceptive nerve fiber terminals in the epidermis and dermis [20] (see Fig. 1). Nociceptors reappear - using PGP 9.5 visualization - over the course of weeks. In the case of Qutenza-induced deinnervation, essentially complete recovery is observed by 24 weeks [21]. Table 2 summarizes available data regarding these effects of topical capsaicin.

\section{TOPICAL CAPSAICIN'S MECHANISMS OF ACTION IN THE SKIN}

The reduction of cutaneous innervation following topical administration of capsaicin may involve a convergent insult on mitochondria. The pharmacological activities of capsaicin and its primary receptor have been widely reviewed [e.g., $22]$, so only summary information is presented here. Capsaicin is a highly selective and potent (low $\mathrm{nM}$ affinity) exogenous agonist for the transient receptor potential vanilloid 1 (TRPV1) receptor, a trans-membrane receptorion channel complex which provides integrated responses to 
Table 1. Survey of changes in cutaneous innervation with peripheral neuropathies, diseases and other disorders assayed primarily by changes in epidermal immunostaining for PGP 9.5 but sometimes other antigens. Values for IENF alterations are derived from comparisons between affected areas and non-painful/unaffected skin or healthy subjects; many of these values were calculated based on other values provided in publications, therefore they should be considered useful approximations but not statistically rigorous. Changes reported in non-cornified skin or mucosal membranes are omitted, as are cancer- or tumor-related alterations

\begin{tabular}{|c|c|c|c|}
\hline $\begin{array}{l}\text { Pain Syndrome, } \\
\text { Disorder or Disease }\end{array}$ & IENF Alteration & Key Findings & References \\
\hline \multirow[t]{2}{*}{ Cancer chemotherapy } & $39 \%$ reduction at 360 days & $\begin{array}{l}\text { Significant reduction in distal leg (but not thigh) IENF density in patients receiving } \\
\text { oxaliplatin } \\
\text { IENF loss continued to worsen following discontinuation of oxaliplatin }\end{array}$ & [64] \\
\hline & $\begin{array}{l}\text { Both decrease and increase of } \\
\text { density during first } 6 \text { months after } \\
\text { baseline }\end{array}$ & $\begin{array}{l}\text { IENF densities can be markedly reduced in cancer patients, even prior to starting } \\
\text { chemotherapy }\end{array}$ & [65] \\
\hline Celiac disease & Reduced in 5 of 8 patients & Neuropathies were diagnosed before celiac disease & {$[66]$} \\
\hline $\begin{array}{l}\text { Complex regional pain } \\
\text { syndrome-1 }\end{array}$ & $\begin{array}{l}71 \% \text { reduction relative to } \\
\text { contralateral control sites }\end{array}$ & Diminished at the CRPS-affected sites of $17 / 18$ subjects & {$[67]$} \\
\hline \multirow[t]{2}{*}{$\begin{array}{l}\text { Diabetes - pancreas } \\
\text { transplantation }\end{array}$} & $\begin{array}{l}96 \% \text { reduction in calf, } 92 \% \text { in } \\
\text { thigh }\end{array}$ & At one month post-transplant for type 1 diabetes, no evidence of regeneration & {$[68]$} \\
\hline & 91 to $93 \%$ reduction in thigh & 2.5 years after pancreas/kidney transplantation, trend towards regrowth of IENFs & [69] \\
\hline \multirow{6}{*}{$\begin{array}{l}\text { Diabetic neuropathy \& } \\
\text { painful diabetic } \\
\text { neuropathy }\end{array}$} & Reduction highly significant & Consistent reduction of epidermal and dermal PGP 9.5 and CGRP fibers & {$[70]$} \\
\hline & $\begin{array}{l}\text { Reduction; significant for } \geq 10 \\
\text { years with disease }\end{array}$ & In epidermis and subepidermis, fiber increase in early diabetes, followed by decrease & [71] \\
\hline & $\begin{array}{l}80 \% \text { reduction, as calculated for } \\
\quad>15 \mathrm{~mm} \text { length epidermis }\end{array}$ & Positive correlation extent IENF reduction and pain severity & {$[72]$} \\
\hline & $81 \%$ reduction & IENF densities declined with duration of diabetes & [73] \\
\hline & $47 \%$ reduction in distal leg & $\begin{array}{l}\text { IENF significantly lower in skin from distal leg in diabetic and non-diabetic neuropathy } \\
\text { patients, but not in the forearm, thigh, or proximal leg } \\
\text { Progressive reduction IENFs from proximal to distal sites }\end{array}$ & {$[74]$} \\
\hline & $\begin{array}{l}69 \% \text { reduction in diabetic } \\
\text { neuropathy, } 42 \% \text { in small-fiber } \\
\text { idiopathic neuropathy }\end{array}$ & TRPV1 immunostaining only in keratinocytes, not IENFs & {$[75]$} \\
\hline $\begin{array}{l}\text { Diabetic truncal } \\
\text { neuropathy }\end{array}$ & Clear reduction in all 3 patients & $\begin{array}{l}\text { Positive correlation extent IENF reduction and pain severity } \\
\text { After clinical recovery, return of IENFs, suggesting that improvement occurs by nerve } \\
\text { regeneration }\end{array}$ & {$[76]$} \\
\hline \multirow[t]{4}{*}{ Fabry disease } & $74 \%$ reduction & All patients had severe loss of IENFs at ankle, but loss at distal thigh was less severe & {$[77]$} \\
\hline & Reduced at baseline & With 6 months of enzyme replacement therapy, no evidence of epidermal reinnervation & {$[78]$} \\
\hline & $\begin{array}{l}\text { Reduced at fingertip (77\%), thigh } \\
\qquad(51 \%) \text {, and leg }(53 \%)\end{array}$ & $\begin{array}{l}\text { IENFs showed morphological abnormalities such as axonal varicosities or swelling } \\
\text { Proximal-distal gradient of ENFD in patients }\end{array}$ & [79] \\
\hline & $\begin{array}{l}54 \% \text { reduction in lower leg; } 75 \% \\
\text { reduction in men with impaired } \\
\quad \text { renal function }\end{array}$ & $\begin{array}{l}\text { Patients with abnormal IENFD more often had pain } \\
\text { Group means for IENFD did not improve following enzyme replacement therapy }\end{array}$ & {$[80]$} \\
\hline \multirow[t]{2}{*}{$\begin{array}{c}\text { Guillain-Barré } \\
\text { syndrome }\end{array}$} & $50 \%$ reduction & $\begin{array}{l}55 \% \text { of patients had degeneration in the dermis, indicated by fragmentation sub-epidermal } \\
\text { nerve plexuses and beaded appearance }\end{array}$ & [81] \\
\hline & $\begin{array}{l}\text { In acute phase, was reduced in } \\
60 \% \text { and } 61.9 \% \text { of patients at } \\
\text { the distal leg and lumbar region, } \\
\text { respectively }\end{array}$ & $\begin{array}{l}\text { In acute phase, } 44 \% \text { of patients complained of neuropathic pain, and their IENFD at the } \\
\text { distal leg was significantly lower than in patients without pain, and correlated with pain } \\
\text { intensity }\end{array}$ & {$[82]$} \\
\hline $\begin{array}{l}\text { HIV-peripheral } \\
\text { neuropathy }\end{array}$ & Reduced & $\begin{array}{l}\text { IENF density inversely correlated with neuropathic pain as measured by patients and } \\
\text { physician global pain assessments } \\
\text { Decreased IENF density at distal leg associated with lower CD4 counts and higher plasma } \\
\text { HIV RNA levels }\end{array}$ & [83] \\
\hline
\end{tabular}


Table 1 contd...

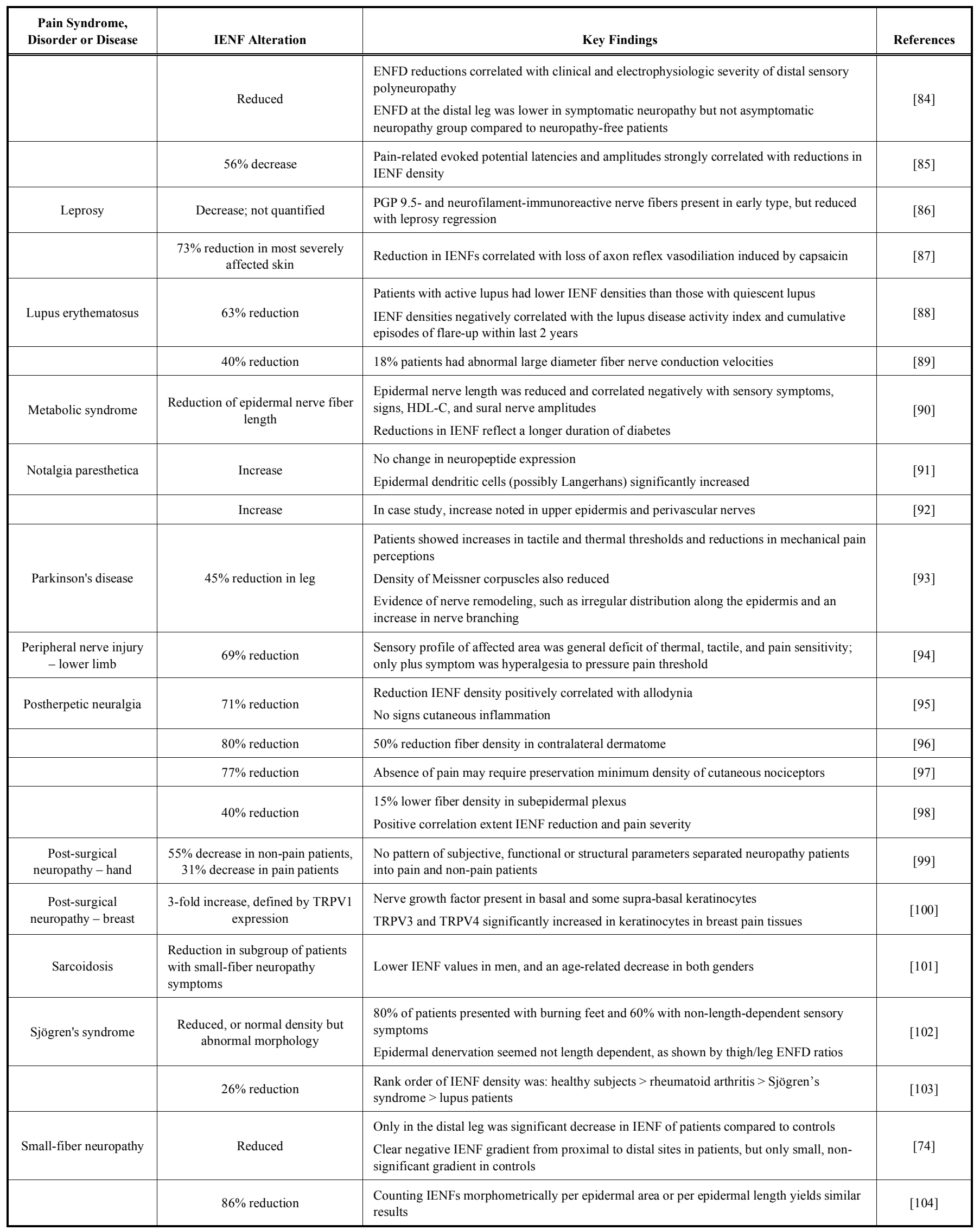


Table 1. contd...

\begin{tabular}{|c|c|c|c|}
\hline $\begin{array}{l}\text { Pain Syndrome, } \\
\text { Disorder or Disease }\end{array}$ & IENF Alteration & Key Findings & Reference \\
\hline & Reduced in $71 \%$ of patients & $\begin{array}{l}\text { Identified associations included abnormal glucose metabolism, Lyme vaccination, } \\
\text { monoclonal gammopathy, vitamin B12 deficiency, } \\
\text { coeliac disease, and diseases of the connective tissue, inflammatory bowel and thyroid; } \\
\text { etiology undetermined in } 50 \% \text { of patients }\end{array}$ & [105] \\
\hline & $\begin{array}{l}\text { Significantly lower (labeled by } \\
\text { TRPV1 and PGP } 9.5 \text { ) in painful } \\
\text { neuropathies, at both proximal } \\
\text { region of the thigh and distal } \\
\text { region of the leg }\end{array}$ & $\begin{array}{l}\text { Densities obtained with TRPV1 antibody did not differ from those with PGP } 9.5 \text { and anti- } \\
\text { unique- } \beta \text {-tubulin }\end{array}$ & [106] \\
\hline Vulvodynia & Increased & $\begin{array}{l}\text { Intraepithelial nerve fiber profiles were not evenly distributed; some areas were almost void } \\
\text { of nerves, whereas other parts were densely } \\
\text { innervated }\end{array}$ & [107] \\
\hline
\end{tabular}

A
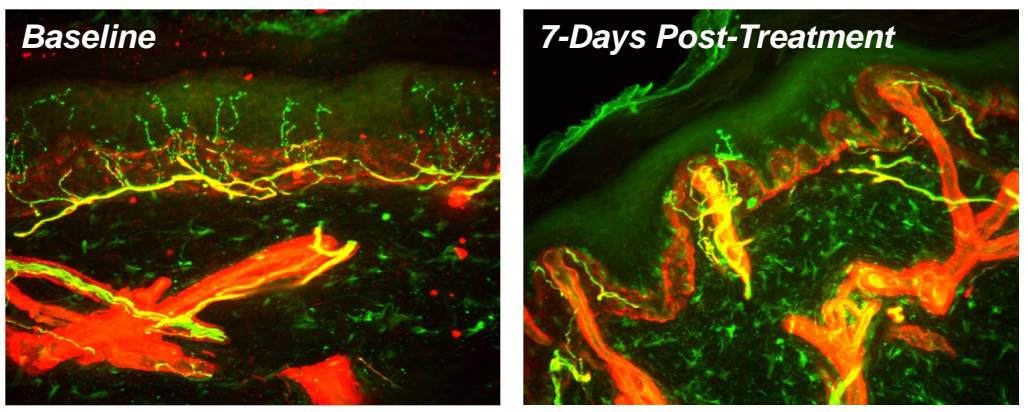

B

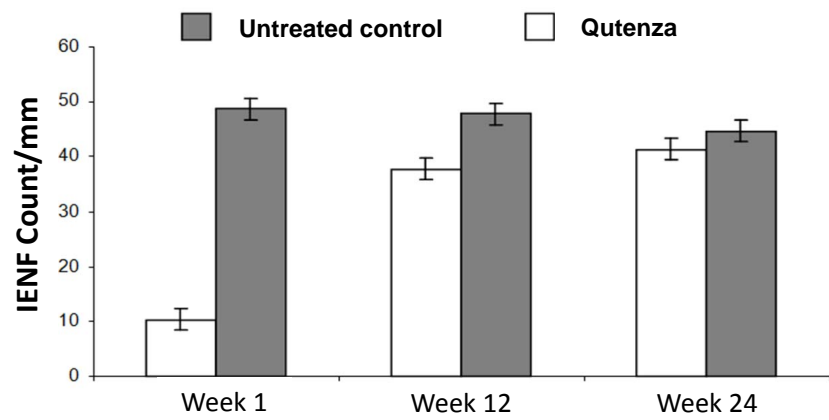

Fig. (1). Visualization of IENFs and time course of Qutenza-induced effects. A) Representative images of intra-epidermal nerve fiber (IENF) density in skin areas exposed to Qutenza for 60 minutes, and in unexposed control areas on the thighs of healthy volunteers. Immunoreactivity to PGP 9.5 is yellow or green, Type IV Collagen is red, and the epidermis is blue. B) Mean reductions in IENF density at 1 , 12 and 24 weeks after a single Qutenza patch application. *indicates $\mathrm{P}<.05$ relative to control. Slightly modified from Kennedy et al., 2010.

temperature, $\mathrm{pH}$ and endogenous lipids. When activated by a combination of heat, acidosis or endogenous/exogenous agonists, TRPV1 opens transiently and initiates a depolarization mediated by influx of sodium and calcium ions. In the nociceptive (mostly $\mathrm{C}$ - and some A $\delta$-fibers) nerve endings which selectively express TRPV1, capsaicinmediated depolarization results in action potentials, which are transmitted to the spinal cord and brain and usually reported as warming, burning, stinging or itching sensations (see Fig. 2).
In contrast to the transient physiological activation of nociceptors which arises from normal environmental stimuli or tissue injury, activation of TRPV1-expressing nerve fibers by capsaicin can be followed by effects on nociceptor functionality and structural integrity [5, 23]. Acutely, inactivation of voltage-dependent sodium channels will reduce electrical excitability, and is often accompanied by the osmotic swelling due to the chloride accumulation that accompanies influxes of positively charged ions [23]. Importantly for persistent effects, the TRPV1 channel is 
Table 2. Effects of capsaicin on IENF density

\begin{tabular}{|c|c|c|c|c|c|c|c|c|c|}
\hline $\begin{array}{c}\text { Drug or } \\
\text { Treatme } \\
\text { nt } \\
\end{array}$ & $\begin{array}{c}\text { Concentration } \\
\text { or Dose; } \\
\text { Pretreatment } \\
\end{array}$ & Total Dose & $\begin{array}{c}\text { Duration \& } \\
\text { Frequency } \\
\text { Exposure } \\
\end{array}$ & $\begin{array}{l}\text { Delivery } \\
\text { Site \& } \\
\text { Method } \\
\end{array}$ & Subjects & $\begin{array}{c}\text { IENF Reduction \& } \\
\text { Time Course }\end{array}$ & ENFD Recovery & $\begin{array}{l}\text { Deeper Effects } \\
\text { \& Other Info } \\
\end{array}$ & $\begin{array}{c}\text { Referenc } \\
\text { es }\end{array}$ \\
\hline Qutenza & $\begin{array}{c}8 \% \text { w } / \text { w patch; } \\
\text { no topical } \\
\text { lidocaine }\end{array}$ & $\begin{array}{c}3 \text { sites, } 3 \times 3 \\
\mathrm{~cm},(640 \\
\left.\mu \mathrm{g} / \mathrm{cm}^{2}\right)\end{array}$ & $\begin{array}{l}\text { Single } 30,60 \\
\& 120 \mathrm{~min}\end{array}$ & $\begin{array}{l}\text { Inner upper } \\
\text { thighs }\end{array}$ & Healthy & $\begin{array}{c}\sim 59 \%(60 \mathrm{~min}), 63 \% \\
(90 \mathrm{~min}) ; \text { at } 7 \text { days }\end{array}$ & N.D. & $\begin{array}{l}\text { Dermal effects } \\
\text { not quantified }\end{array}$ & [48] \\
\hline Qutenza & $\begin{array}{c}8 \% \text { w } / \text { w patch; } \\
\text { no topical } \\
\text { lidocaine }\end{array}$ & $\begin{array}{c}3 \text { sites, } 5 \mathrm{x} \\
5.5 \mathrm{~cm},(640 \\
\left.\mu \mathrm{g} / \mathrm{cm}^{2}\right)\end{array}$ & Single $60 \mathrm{~min}$ & $\begin{array}{l}\text { Inner upper } \\
\text { thighs }\end{array}$ & Healthy & $\begin{array}{l}\sim 80 \% \text { (7 days), } 20 \% \\
\text { (12 wk), } 7 \%(24 \mathrm{wk})\end{array}$ & $\begin{array}{c}80 \% \text { recovery } 12 \\
\text { wk, } 93 \% \text { at } 24 \\
\text { wk }\end{array}$ & $\begin{array}{l}\text { Reduction in } \\
\text { dermis, not } \\
\text { quantified }\end{array}$ & [21] \\
\hline Qutenza & $\begin{array}{c}8 \% \text { w } / \text { w patch; } \\
30 \text { min } 4 \% \\
\text { lidocaine }\end{array}$ & 1 site & Single $60 \mathrm{~min}$ & $\begin{array}{l}\text { Inner upper } \\
\text { thighs }\end{array}$ & Healthy & $\sim 71 \%$ at 7 days & N.D. & N.D. & [109] \\
\hline $\begin{array}{l}\text { NGX- } \\
1998\end{array}$ & $\begin{array}{c}10 \% \mathrm{w} / \mathrm{v} ; 30 \\
\min 4 \% \\
\text { lidocaine }\end{array}$ & $\begin{array}{c}3 \text { sites, } 5 \times 5 \\
\mathrm{~cm}, \sim 6 \\
\mu \mathrm{L} / \mathrm{cm}^{2}\end{array}$ & $\begin{array}{l}\text { Single } 5,15 \& \\
25 \mathrm{~min}\end{array}$ & $\begin{array}{l}\text { Inner upper } \\
\text { thighs }\end{array}$ & Healthy & $\begin{array}{c}70 \%(5 \& 15 \mathrm{~min}) \& \\
73 \%(25 \mathrm{~min}) \text { at } 7 \\
\text { days }\end{array}$ & N.D. & N.D. & [109] \\
\hline $\begin{array}{l}\text { NGX- } \\
1998 \& \\
\text { NGX- } \\
4162\end{array}$ & $\begin{array}{l}10 \% \mathrm{w} / \mathrm{v} ; \text { no } \\
\text { topical lidocai- } \\
\text { ne }\end{array}$ & $\begin{array}{c}3 \text { sites, } 5 \text { x } 5 \\
\mathrm{~cm}, 15 \\
\mu \mathrm{L} / \mathrm{cm}^{2}\end{array}$ & Single $15 \mathrm{~min}$ & $\begin{array}{l}\text { Inner upper } \\
\text { thighs }\end{array}$ & Healthy & $\begin{array}{c}34 \%(\text { NGX-1998) \& } \\
33 \%(\text { NGX-4162) at } \\
7 \text { days }\end{array}$ & N.D. & N.D. & [110] \\
\hline Capsaicin & $0.1 \%$ cream & $2 \times 1800 \mathrm{mg}$ & $\begin{array}{c}48 \mathrm{hr}(2 \times 24 \\
\mathrm{hr})\end{array}$ & $\begin{array}{l}\text { Distal } \\
\text { lateral } \\
\text { thigh; } \\
\text { Under } \\
\text { occlusion }\end{array}$ & $\begin{array}{l}\text { Healthy } \\
\& \\
\text { Diabetic }\end{array}$ & $>99 \%$ & $\begin{array}{c}\text { Rate } \\
\text { reinnervation } \\
0.18 \text { (healthy), } \\
0.07 \text { (diabetics) } \\
\text { fibers/mm/day; } \\
\text { Diabetics } 42 \% \text { of } \\
\text { healthy; } \\
\text { Incomplete } \\
\text { regrowth at } 100 \\
\text { days }\end{array}$ & $\begin{array}{l}\text { Subepidermal- } \\
\text { dermal plexus } \\
\text { deinnervated }\end{array}$ & [46] \\
\hline Capsaicin & $0.1 \%$ cream & $2 \times 1800 \mathrm{mg}$ & $\begin{array}{c}48 \mathrm{hr}(2 \times 24 \\
\mathrm{hr})\end{array}$ & $\begin{array}{l}\text { Distal } \\
\text { lateral } \\
\text { thigh; } \\
\text { Under } \\
\text { occlusion }\end{array}$ & $\begin{array}{c}\text { HIV- } \\
\text { infected } \\
\& \\
\text { Healthy }\end{array}$ & $>99 \%$ & $\begin{array}{c}\text { Rate } \\
\text { reinnervation } \\
0.17 \text { (healthy), } \\
0.13(\mathrm{HIV}+), \\
0.10(\mathrm{HIV}-\mathrm{PN}) \\
\text { fibers } / \mathrm{mm} / \text { day }\end{array}$ & $\begin{array}{l}\text { Subepidermal- } \\
\text { dermal plexus } \\
\text { deinnervated }\end{array}$ & {$[73]$} \\
\hline Capsaicin & $0.1 \%$ cream & $2 \times 1800 \mathrm{mg}$ & $\begin{array}{c}48 \mathrm{hr}(2 \times 24 \\
\mathrm{hr})\end{array}$ & $\begin{array}{l}\text { Volar } \\
\text { forearm; } \\
\text { Under } \\
\text { occlusion }\end{array}$ & Healthy & $>99 \%$ & $\begin{array}{l}150 \text { days for full } \\
\text { regeneration }\end{array}$ & $\begin{array}{l}\text { Reduction in } \\
\text { sudomotor, } \\
\text { vasomotor, } \\
\text { pilomotor, and } \\
\text { sensory function }\end{array}$ & {$[47]$} \\
\hline Capsaicin & $0.1 \%$ cream & $2 \times 1800 \mathrm{mg}$ & $\begin{array}{c}48 \mathrm{hr}(2 \times 24 \\
\mathrm{hr})\end{array}$ & $\begin{array}{l}\text { Distal } \\
\text { lateral } \\
\text { thigh; } \\
\text { Under } \\
\text { occlusion }\end{array}$ & $\begin{array}{l}\text { Diabetic } \\
\& \\
\text { Healthy }\end{array}$ & $>99 \%$ & $\begin{array}{c}\text { Rate } \\
\text { reinnervation } \\
0.19 \text { (healthy), } \\
0.09 \text { (diabetes) } \\
\text { fibers } / \mathrm{mm} / \text { day }\end{array}$ & $\begin{array}{l}\text { GAP-43 } \\
\text { staining not } \\
\text { extend into } \\
\text { epidermis }\end{array}$ & [112] \\
\hline Capsaicin & $\begin{array}{l}\text { Injection } 0.2,2 \\
\quad \text { or } 20 \mu \mathrm{g}\end{array}$ & $5 \mathrm{~mm}$ area & $\begin{array}{l}\text { Up to } 7 \\
\text { injections }\end{array}$ & $\begin{array}{l}\text { Lateral } \\
\text { aspect } \\
\text { upper arm } \\
\text { (shoulder) }\end{array}$ & Healthy & $\begin{array}{l}\sim 100 \% \text { at } 72 \mathrm{hr} \text { for } 2 \\
\text { or } 20 \mu \mathrm{g}\end{array}$ & $<50 \%$ at $6 \mathrm{wk}$ & $\begin{array}{c}\text { Small to } \\
\text { moderate } \\
\text { decrease } \\
\text { subepidermal } \\
\text { plexus }\end{array}$ & [113] \\
\hline Capsaicin & $0.075 \%$ cream & $35 \mathrm{~cm}^{2}$ & $\begin{array}{l}4 \text { times daily } \\
\text { for } 3 \mathrm{wk}\end{array}$ & $\begin{array}{l}\text { Inner arm } \\
\text { or volar } \\
\text { forearm }\end{array}$ & Healthy & $82 \%$ at $3 \mathrm{wk}$ & $\begin{array}{l}\text { After } 6 \text { wk, } 88 \% \\
\text { recovery }\end{array}$ & $\begin{array}{c}\text { Little effect } \\
\text { subepidermal } \\
\text { plexus or dermis }\end{array}$ & [20] \\
\hline Capsaicin & $0.075 \%$ cream & $4 \times 5 \mathrm{~cm}$ & $\begin{array}{l}4 \text { times day for } \\
7 \text { days }\end{array}$ & $\begin{array}{l}\text { Volar } \\
\text { forearm }\end{array}$ & Healthy & $\sim 100 \%$ after 6 days & $\sim 50 \%$ after $5 \mathrm{wk}$ & $\begin{array}{c}\text { No effect } \\
\text { subepidermal } \\
\text { plexus or dermis }\end{array}$ & [114] \\
\hline Capsaicin & $\begin{array}{l}0.075 \% \text { dried } \\
\text { on disk, } \\
\text { applied }\end{array}$ & $\begin{array}{c}2.5 \mathrm{~cm} \\
\text { diameter }\end{array}$ & $\begin{array}{l}\text { Single 5- } \\
\text { minute } \\
\text { application (?) }\end{array}$ & $\begin{array}{l}\text { Volar } \\
\text { forearm }\end{array}$ & Healthy & $\begin{array}{l}\text { Significant reduction } \\
\text { PGP 9.5, complete } \\
\text { loss sub P }\end{array}$ & N.D. & N.D. & [115] \\
\hline Capsaicin & $0.075 \%$ cream & $\begin{array}{l}3.5 \mathrm{gm} \\
\text { cream under } \\
\text { occlusion, } 5 \\
\text { x } 5 \mathrm{~cm}\end{array}$ & $\begin{array}{c}3 \text { times for } 24 \\
\mathrm{hr}\end{array}$ & $\begin{array}{l}\text { Lateral } \\
\text { distal calf }\end{array}$ & Healthy & $\begin{array}{l}93 \% \text { at end of dosing } \\
(72 \mathrm{hr})\end{array}$ & $\begin{array}{c}\text { Recover to } 40 \% \\
\text { at } 26 \text { days; } 56 \% \\
\text { at } 54 \text { days }\end{array}$ & $\begin{array}{l}\text { GAP-43 } \\
\text { staining: less } \\
\text { reduction, much } \\
\text { faster return, } \\
\text { little in } \\
\text { epidermis }\end{array}$ & {$[16]$} \\
\hline
\end{tabular}




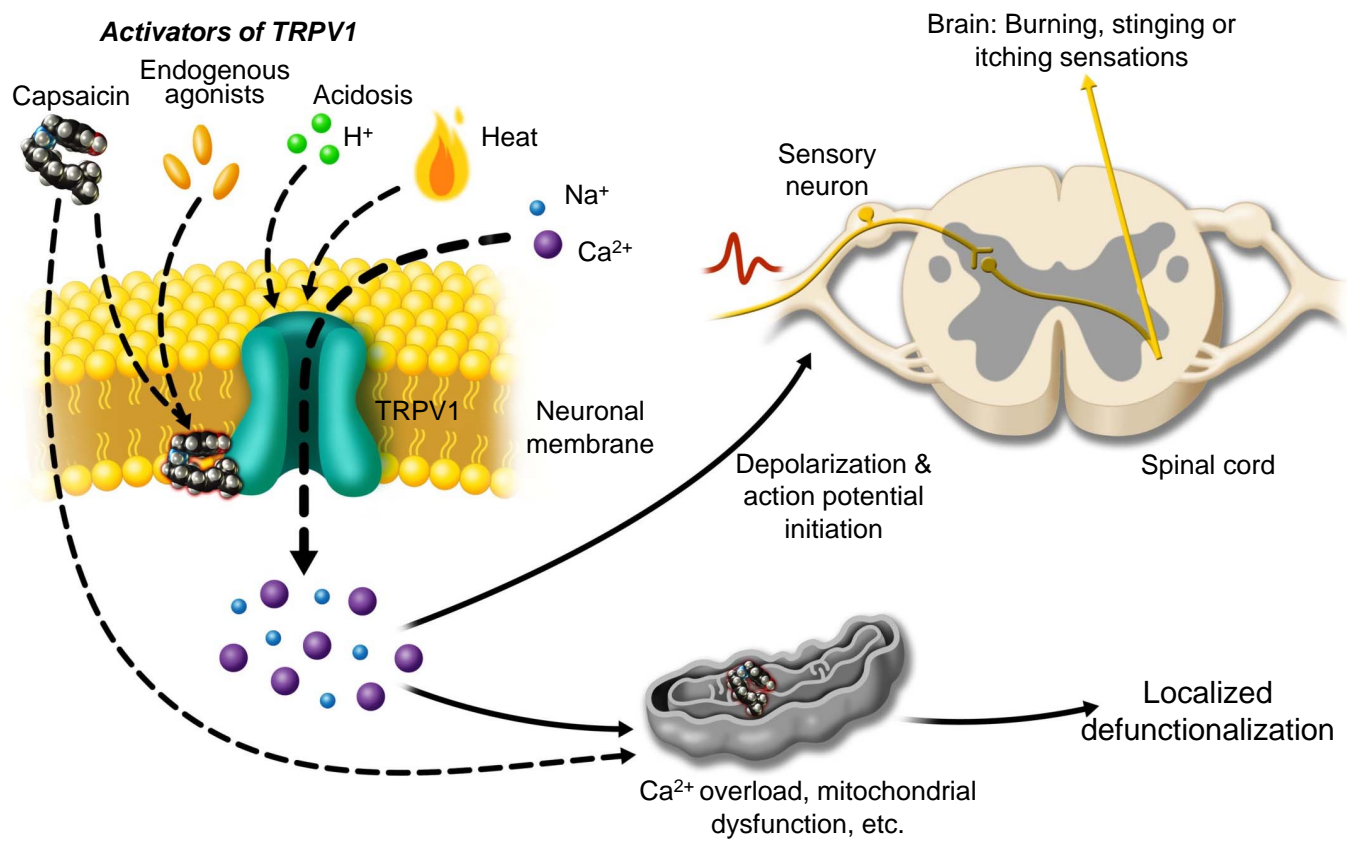

Fig. (2). Activation of TRPV1 by capsaicin results in sensory neuronal depolarization, and can induce local sensitization to activation by heat, acidosis, and endogenous agonists. Topical exposure to capsaicin leads to the sensations of heat, burning, stinging, or itching. High concentrations of capsaicin or repeated applications can produce a persistent local effect on cutaneous nociceptors, which is best described as 'defunctionalization' and constituted by reduced spontaneous activity and a loss of responsiveness to a wide range of sensory stimuli. Taken from Anand and Bley, 2011.

highly calcium permeable (with a calcium:sodium permeability ratio that is as high as 25:1) [24], which can produce dramatic increases in intracellular calcium. TRPV1 is also expressed on the endoplasmic reticulum, so capsaicin can additionally cause an intracellular release of calcium [25]. High intracellular calcium can additionally induce release from internal stores via calcium-dependent calcium release [26]. These multiple sources of calcium can overwhelm local calcium sequestration mechanisms, thereby activating calcium-dependent enzymes such as proteases [27] and inducing depolymerization of cytoskeletal components such as microtubules [28, 29].

Mitochondria are not randomly distributed throughout the sensory neuron but rather accumulate at regions of increased energy consumption, for example, at the sites of sensory transduction [30]. Numerous mitochondria are present in the peripheral terminals of nociceptors and may congregate there in response to nerve growth factor signaling. The primary insult to nociceptor function from capsaicin exposure is a robust intracellular calcium signal, which is sometimes sufficient to overload the calcium sequestration capabilities of mitochondria [23]. In addition, it is possible that topical capsaicin administration particularly from high-concentration formulations such as Qutenza - may provide sufficiently high cutaneous capsaicin concentrations to enable secondary pharmacodynamic mechanisms to contribute to long-term effects on nociceptors. As observed in the context of the anti-cancer effects of capsaicin, TRPV1-independent effects may involve direct inhibition of mitochondrial respiration [31]. At concentrations much higher than required to activate TRPV1, capsaicin can compete with ubiquinone to inhibit directly electron chain transport [32]. Consequently, capsaicin may directly dissipate mitochondrial trans- membrane potential [33]. The $\mathrm{EC}_{50}$ value for capsaicin to depolarize mitochondria in sensory neurons is $6.9 \mu \mathrm{M}$, a concentration much great than required to activate TRPV1 [34]; it is not known whether this high concentration reflects a contribution from a direct effect on mitochondrial respiration.

Loss of mitochondrial function due to calcium overload and possible inhibition of metabolism may render affected nerve processes unable to maintain plasma membrane integrity and thus cause collapse of nerve endings to the depth where the capsaicin exposure was insufficient to irreversibly overwhelm mitochondrial function (see Fig. 3). If nerve fibers in skin retract or degenerate to the depth at which mitochondrial function was preserved, it is expected that markers for any constituent of those fibers will show reductions. However, it is important to recognize that loss of function and nerve terminal degeneration are distinct phenomena, each with potentially different time courses. In the simplest case, a loss of electrical excitability may occur via depolarization block or sodium channel inactivation, independently of a loss of axonal integrity. Other important physiological roles such as fast axonal transport of growth factors can also be compromised by capsaicin without axonal collapse [35]. Even though a general parallel between capsaicin-induced functional and structural changes is expected, there may be differences in the time courses.

The term 'desensitization' is often used to describe both the acute and persistent effects of capsaicin on sensory nerve function, but is unsatisfactory in several respects. The use of this nomenclature arose many years ago from psychophysical studies of human subjects who displayed reduced reactions to painful stimuli applied to skin areas pretreated with capsaicin [36]. Unfortunately, once the 


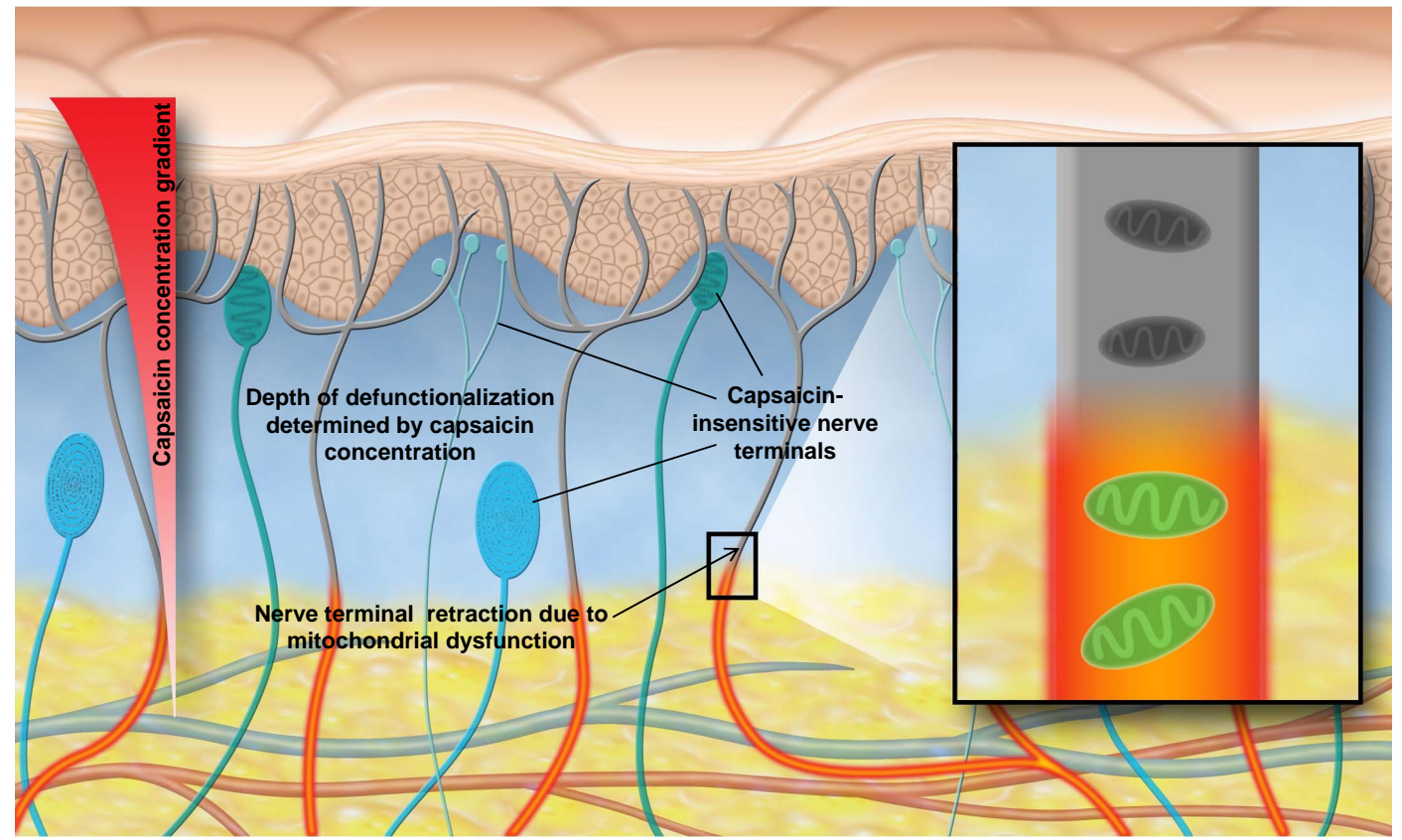

Fig. (3). Depiction of the site of action of topical capsaicin in the epidermis and dermis. Owing to near insolubility in water, capsaicin is not readily absorbed into the microvasculature. When cutaneous nociceptors are hypersensitive and sometimes spontaneously active, localized defunctionalization of capsaicin-responsive cutaneous nociceptive terminals can reduce the afferent barrage which may drive pain syndromes. Inset shows how mitochondrial dysfunction leads to nerve terminal necrosis. Taken from Anand and Bley, 2011.

capsaicin receptor (TRPV1) was recognized as a unique molecule entity, the psychophysical use of 'desensitization' evolved into pharmacological use, which denotes the reduction of responsiveness of an ion channel-receptor complex following prolonged or repeated agonist exposures. In the continued presence of exogenous agonists such as capsaicin, pharmacological desensitization of TRPV1 itself may indeed contribute acutely to analgesic efficacy. However, transient effects on TRPV1 are quite unlikely to account for the persistent pain relief seen clinically following either single treatments with high-concentration capsaicin or repetitive administration of low-concentration capsaicin. Hence, in my opinion, the least inaccurate term for the persistent local effects of capsaicin is 'defunctionalization', which avoids conceptual confusion with the intrinsic desensitization of the TRPV1 receptor. The multiple aspects of capsaicin-induced loss of sensory nerve function have been appreciated for many years [23]. Degeneration or necrosis may occur, but the absence of a panel of antigens is required to determine that nerve terminals are truly absent.

\section{DOSE RESPONSE AND THE MITIGATION OF PUN- GENCY}

Evolutionary selective pressures seem to have maximized the pungency of capsaicin. According to the 'directeddeterrence' hypothesis, the key driver for the expression of capsaicin may be that the compound's pungency is able to deter ambulatory animals from eating chili pepper fruits, with selective pressures favoring those plants whose seeds were dispersed widely by birds [37]. The TRPV1 receptor of birds is not activated by capsaicin [38], and hence they are undeterred from ingesting chili pepper fruits and can excrete the pepper seeds large distances away.

The assumption that pungency is inevitably associated with capsaicin administration has caused researchers to investigate the therapeutic potential of less pungent compounds such as resiniferatoxin [39] and olvanil [40]. From comparative studies of various TPRV1 agonists, it appears that the rate of channel activation is the best predictor for pungency, with capsaicin being the most pungent and most rapidly activating compound [41].

Long ago it was hypothesized that if capsaicin were delivered to a target sensory neuron sufficiently quickly that the defunctionalization process could occur almost as rapidly as the activation process, thereby rending well tolerated the capsaicin-based treatment [42]. Clinical data to support a capsaicin exposure-pungency relationship which plateaus has been provided by the clinical development program for Qutenza and its successor formulation. Qutenza was well tolerated in clinical studies, with greater than $98 \%$ of subjects being able to complete 30 - to 60 -minute treatment durations without asking for early removal of the patches [43]. These results might be surprising if the pain associated with the treatment procedure of a formulation containing 80fold more capsaicin than the highest concentration OTC cream were expected to be 80 times more pungent. Even more instructive is the clinical data for NGX-1998, which is the successor non-patch/liquid formulation of capsaicin. A Phase 2 study of NGX-1998 in patients with postherpetic neuralgia revealed excellent tolerability to the treatment procedure even in the absence of a local anesthetic pretreatment $[11,44]$. There were no differences in tolerability between the $10 \%$ and $20 \% \mathrm{w} / \mathrm{w}$ versions of NGX-1998 even though the $20 \%$ form displayed more efficacy. It is likely that future clinical studies will utilize only $20 \%$ capsaicin.

Combined with preexisting theory, data emerging from the development programs of the high-concentration topical formulations Qutenza and NGX-1998 enables inferences about the dose-response relationship of topical capsaicin. 


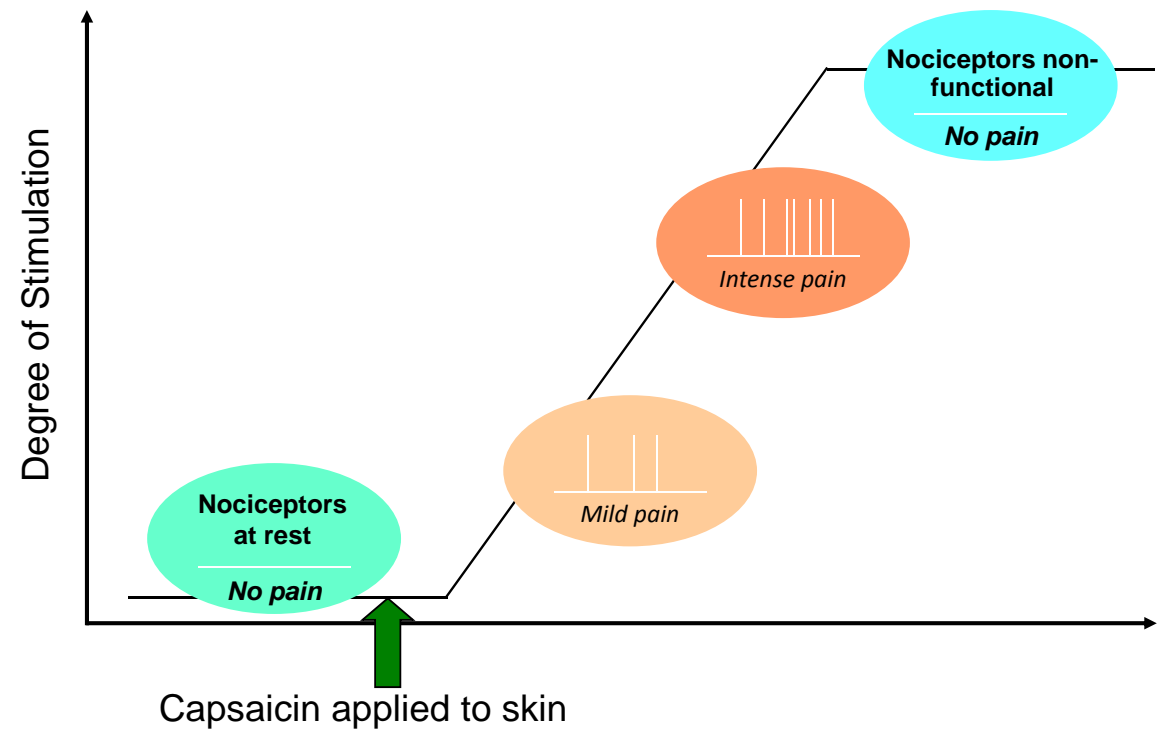

Fig. (4). Theoretic basis for topical capsaicin's dose-response relationship. In normal skin without spontaneously active nociceptors, capsaicin administration will induce activation of nociceptors. However, the parallel process of defunctionalization is also initiated, and if the capsaicin exposure is sufficient, the nociceptors will cease to function, resulting in decreased afferent barrage and pain. This oversimplification ignores the cutaneous concentration gradient and the activation without defunctionalization that may occur in the dermis.

Two types of outcomes must be considered: persistent pain relief and short-term pungency and tolerability. It must also be recognized that a topical dose is constituted not only by the formulation's drug concentration but also the duration of application, plus the volume for liquid formulations such as NGX-1998. Overall, the shape of the capsaicin-pain relief dose-response curve is rather shallow, with only modest benefit generally observed with 60 - or 90-minute patch applications of Qutenza relative to 30 minutes. One articulation for these data is that for each single hyperactive cutaneous nociceptive nerve fiber, there is a 'tipping point' at which a capsaicin exposure results in irreversible damage and degeneration. Bringing a sufficient number of hyperactive cutaneous nociceptors in a painful area to their tipping point and causing their defunctionalization/degeneration can yield discernible pain relief.

With respect to short-term tolerability, the dose-response curve appears to become flat at high concentrations and may become bell-shaped. As is depicted in Fig. (4), highconcentration topical capsaicin formulations may push nociceptors into a defunctionalized state almost as quickly as they are activated, thereby reducing sensations of pungency and thereby improving tolerability.

\section{IMPORTANCE OF LOCAL CONCENTRATIONS, DELIVERY RATE AND FORMULATION COMPO- NENTS}

The skin pharmacokinetics of drug substances and formulation excipients released by topical formulations are sometime either unstudied or unreported. All of these data are important for consideration of potential secondary pharmacokinetics of applied drug substances and evaluation of possible actions of 'inactive' formulation components.

Cutaneous drug delivery is very inefficient - meaning that often only 1 to $3 \%$ of the applied drug will partition into skin - so excessive amounts are applied to increase the concentration gradient. Adding complexity is that drugs substances may be preferentially localized or solubilized in just one component of the formulation. For instance, the overall concentration of capsaicin in the Qutenza patch is $8 \%$ on a percentage $\mathrm{w} / \mathrm{w}$ basis. However, capsaicin is mostly contained within the patch in microreservoirs in which it is solubilized at $28 \% \mathrm{w} / \mathrm{v}$ in a skin penetration enhancer. To consider the implications of this concentration, $28 \%$ is roughly equivalent to $918 \mathrm{mM}$. Similarly, the approximate concentration of capsaicin in the 20\% NGX-1998 formulation is $656 \mathrm{mM}$. Assuming $2 \%$ or less of the capsaicin is absorbed into the skin, it is not possible to arrive at a prediction of concentrations in the epidermis or dermis due to the significant depoting which will occur in the stratum corneum [45]. The potency of capsaicin at TRPV1 at $32{ }^{\circ} \mathrm{C}$ is less than $0.1 \mathrm{nM}$ and (as was discussed above) secondary pharmacodynamic effects may begin in the range of about $3 \mu \mathrm{M}$. It remains unknown to what degree topically applied capsaicin can attain the latter concentration.

To illustrate to complexities of skin pharmacokinetics, consider an innovative model to study skin reinnervation after complete deinnervation developed at Johns Hopkins University [46]. The model is based upon a 48-hour application of a $0.1 \% \mathrm{w} / \mathrm{w}$ capsaicin cream under occlusion to the distal legs of either healthy control or patients with peripheral neuropathies. The capsaicin cream is removed and reapplied after 24 hours. Immunohistochemical analyses of punch biopsies reveal that essentially all intra-epidermal nerve fibers are lost. Another group has reported that in addition to nearly complete loss of PGP 9.5 immunostaining, when applied to the volar forearm, reductions in sudomotor, vasomotor, pilomotor and sensory functions and the densities of associated nerve fibers occurred [47]. The authors of this study find the loss of not only sensory but also sympathetic and parasympathetic nerve fibers worrisome and concluded that, "...caution should be taken when topical capsaicin is applied to skin surfaces at risk for ulceration, particularly in neuropathic conditions characterized by sensory and autonomic impairment." 
The observation of ablation of nerve fibers not restricted to a subset of sensory fibers in the publication above contradicts numerous previous studies with capsaicin. Moreover, given the substantial and rapid delivery of capsaicin from Qutenza, it is somewhat surprising that the high-concentration patch reduces IENF density less than other treatments: based on PGP 9.5 analyses, with the Johns Hopkins model and rigorous repeated applications of overthe-counter (OTC) low-concentration creams [20] essentially all IENFs disappear, whereas with Qutenza only 59 to $80 \%$ of IENFs are lost $[21,48]$. The complete disappearance of IENF immunostaining could be explained if the 48-hour occlusive administration of the Johns Hopkins model or repeated applications of OTC creams resulted in an accumulation of more capsaicin in the skin than is provided by Qutenza. However, in a robust porcine model of capsaicin skin pharmacokinetics, application of the same $0.1 \%$ cream for 48 hours under occlusion did not induce a quantifiable difference in capsaicin content relative to a 1-hour administration of a $0.075 \%$ cream, and both of these treatments provided substantially less skin capsaicin than followed a single Qutenza application for 60 minutes (S. Babbar, personal communication).

For an alternative explanation of the effect size on IENF density, it may be interesting to consider the excipients of the topical creams. The Johns Hopkins model has consistently employed Capzasin ${ }^{\circledR}(0.1 \%)$ HP Arthritis Pain Relief from Chattem, Inc. (Chattanooga, TN, USA). The following are the inactive ingredients, which are listed in descending order of predominance: benzyl alcohol, cetyl alcohol, glyceryl stearate, isopropyl myristate, PEG-40 stearate, petrolatum, sorbitol and water. There is no concentration information required for 'inactive' ingredients in OTC products. Whatever the concentration, benzyl alcohol is certainly of interest, as topical administration appears to leads its accumulation in the epidermis [49] and benzyl alcohol has long been recognized to be a neurotoxin $[50,51]$. Detailed analyses of the underlying mechanisms of neurotoxicity have recently shown that benzyl alcohol is a mitochondrial toxicant capable of compromising mitochondrial integrity and initiating pro-apoptotic cascades [52]. Unfortunately, there is no information about whether the control cream employed by groups using the Johns Hopkins model contains any benzyl alcohol. Repeating the above experiments with a true matching control cream may be necessary, and it would be extremely interesting to apply benzyl alcohol under occlusion for 48 hours and determine effects on nociceptors. It is also possible that benzyl alcohol has an additive or even synergistic neurotoxicity with capsaicin, which might explain the loss of all types of nerves fibers observed by Gibbon and colleagues [47]. As a general rule, before any rigorous efficacy or safety inferences can be made regarding a drug substance, it is necessary to exclude the potential effects of excipients which may not be inactive at the high concentrations attained in the skin.

\section{SECONDARY PHARMACODYNAMICS AND PO- TENTIAL COMMON MECHANISMS WITH TOPI- CAL LIDOCAINE}

Lidocaine is also widely used as a topical analgesic. In particular, the Lidoderm ${ }^{\circledR}(5 \% \mathrm{w} / \mathrm{w}$ lidocaine $)$ patch was approved in the US in 1999 for the management of
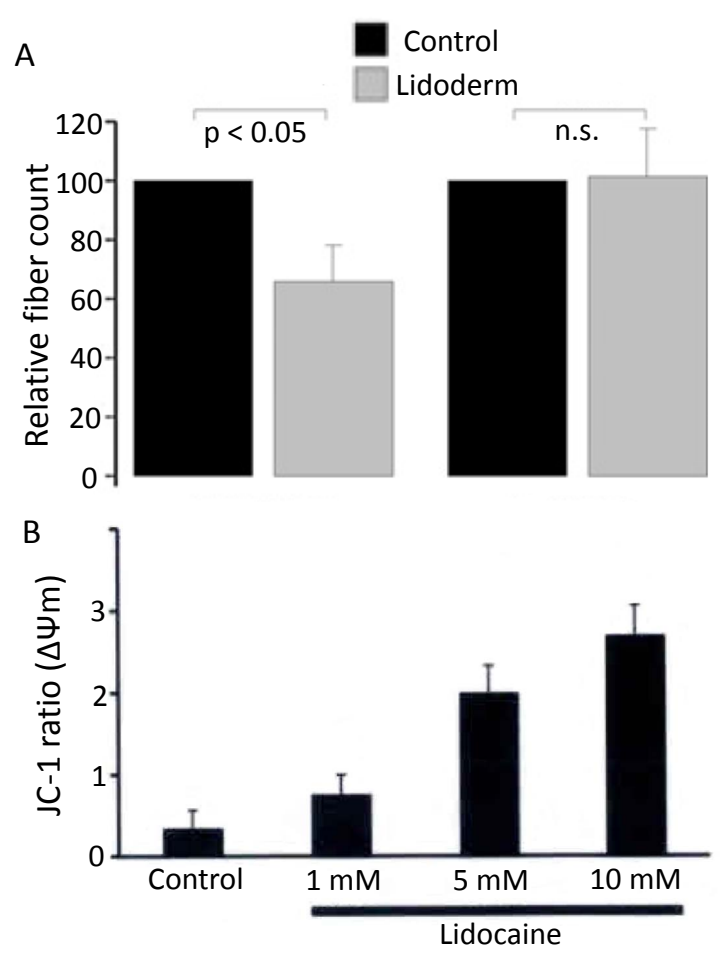

Fig. (5). Lidoderm induces structural changes in cutaneous nociceptors that may be mediated by toxicity to mitochondrial. A) Lidoderm patches applied to volar forearms of healthy subjects for 12 hours per day every day for 41 days decreases IENF density. Skin blisters provided the samples for the IENF counts. Taken from Wehrfritz, 2011. B) Lidocaine depolarizes mitochondria. The external solution of rat dorsal root ganglion cultures was changed to the indicated concentration for 5 minutes, and mitochondrial membrane potentials $\left(\Delta \Psi_{\mathrm{m}}\right)$ were determined using the fluorescent dye JC-1. Taken from Onizuka, 2011.

postherpetic neuralgia. The same patch is sold in the EU and other countries under the trade name of Versatis ${ }^{\circledR}$ [53]. Lidoderm patches are applied directly to the painful area and worn chronically for 12-hour cycles. Unlike topical formulations intended to produce full anesthesia, the generally attributed analgesic mechanism of action of Lidoderm is that the sub-anesthetic concentrations of lidocaine provided by the patch selectively inhibit the activity of hyperactive cutaneous nociceptors [54]. Interestingly, a combination QST-biopsy study reveals that Lidoderm not only elevated thresholds for nociceptor activation at the application site, but also decreased IENF densities after 41 days of administration (see Fig. 5A) [55].

How is the topical lidocaine reducing IENF density? In contrast to the high selectivity of capsaicin for the TRPV1 receptor at concentrations less than $1 \mu \mathrm{M}$, lidocaine appears to have multiple effects at concentrations that are considered therapeutically relevant for inhibition of voltage-activated sodium channels. In the case of Lidoderm, which is a $5 \%$ w/w patch in an aqueous matrix, the overall concentration of lidocaine in the patch is calculated to be $213 \mathrm{mM}$. Three percent cutaneous bioavailability has been reported for Lidoderm [56], but this value reflects both cutaneous and transdermal delivery. In a study of human with a $5 \%$ cream 
formulation, the delivery to skin was $109 \mathrm{ng} / \mathrm{mm}^{2}$ [57], but no concentration information was provided on a molar basis. Like capsaicin, lidocaine will depot in the stratum corneum, but because it is less lipophilic than capsaicin, the degree of depoting should be less [45].

In addition to the best known activity as a use-dependent $\mathrm{Na}^{+}$channel blocker, lidocaine and its main metabolite inhibit hyperpolarization-activated and cyclic nucleotidegated $(\mathrm{HCN})$ channels that contribute to pacemaker currents [58]. Lidocaine can also directly activate TRPV1 and modulate activation by capsaicin [59]. Importantly for the present discussion, millimolar lidocaine concentrations are known to be neurotoxic. In cultured rat sensory neurons, lidocaine induces morphological changes such as varicosity formation and apoptosis [60]. Direct effects on mitochondria may underlie the neurotoxicity (see Fig. 5B) [61, 62], possibly suggesting a shared mechanism with capsaicin.

The importance of delivery rate and excipients call into question the notion that 'bioequivalence' can be demonstrated for a topical analgesic based solely on cutaneous drug concentrations. Total accumulation of a drug in the skin may not fully reflect or predict efficacy or adverse effects: drug concentration, duration of application, number of times applied per day, rate of delivery, whether applied under occlusion and excipients all matter. Recently, Endo Pharmaceuticals filed a Citizen's Petition to the FDA regarding generic versions of Lidoderm which raised many of these same issues [63]. Endo argues that skin pharmacokinetic studies are not sufficient and that clinical efficacy studies must be conducted to prove that two topical products produce the same degree of pain relief.

\section{CONCLUSIONS}

Even though topical capsaicin has been used for centuries as an analgesic, the first formal review of capsaicin by drug regulatory agencies occurred during the recent approval process for a single-use high-concentration topical capsaicin patch to manage peripheral neuropathic pain. The clinical validation of Qutenza and the continued success of Lidoderm/Versatis have reinvigorated interest in topical approaches to pain management.

Changes in cutaneous innervation result from many pain syndromes and other disorders. As a general rule, the severity of innervation loss seems to positively correlate with degree of pain. This relationship underlies the often noted paradoxical nature of peripheral neuropathies: pain intermingled with numbness. Functional evaluations of cutaneous innervation are very useful, but for the purposes of comparing across studies or institutions, data from immunostaining of punch biopsies with antigens such as PGP 9.5 can more readily be discussed in review articles such as this one. However, it should never be assumed that PGP 9.5 immunostaining can tell the whole story, particularly for regenerating cutaneous nerve endings.

Clear reductions of PGP 9.5 immunostaining occur following topical administration of capsaicin. Such reductions are not restricted to the epidermis but also occur in the dermis. However, because of the complexity in quantifying reductions in the dermis, these values are usually not determined. Little or no information is available on the depth of capsaicin penetration and to what degree it ablates nociceptive fibers in the dermis.

It is wrong to focus exclusively on the concentration of drug content when evaluating or comparing topical formulations: concentration, duration of application, applications per day and excipients all matter. Skin concentrations of drug substances and excipients may be quite high and induce both primary and secondary pharmacodynamic responses. Excipients that are normally benign or inactive when diluted in large volumes may accumulate in skin layer and produce toxicities. Mitochondria-rich cutaneous nociceptors are perhaps the most vulnerable structure in the skin, and mitochondrial toxicants may readily cause collapse of the highly metabolically active nociceptive nerve terminals. Topical capsaicin and lidocaine share an ability to cause the localized degeneration of nociceptors, possibly through deleterious effects on mitochondria.

Another implication of the complexity of topical formulations is that efficacy or safety of drug produces such as Qutenza cannot be based upon data from OTC products or experimental models. In particular, data from the Johns Hopkins models showing the loss of all cutaneous nerve fibers should not be considered relevant for predicting potential adverse effects of Qutenza or other topical capsaicin formulations. 'Bioequivalence' based upon capsaicin delivery to skin is not a helpful concept - each formulation requires clinical data to confirm that it actually produces pain relief, irrespective of how much of a drug substance is delivered into skin.

In summary, even though the skin is the most accessible of all human organs, much remains to be learned about how its innervation changes and the effects of drugs on that innervation. The pharmacokinetics and pharmacodynamics of topical analgesics such as capsaicin and lidocaine should not be assumed to be less complex than orally administered analgesics.

\section{CONFLICT OF INTEREST}

Keith Bley was formerly employed by NeurogesX, Inc., which developed and marketed the Qutenza (8\% capsaicin) patch.

\section{ACKNOWLEDGEMENTS}

Declared none.

\section{REFERENCES}

[1] Turnbull A. Tincture of capsaicin as a remedy for chilblains and toothache. Dublin Free Press 1850; 1: 95-6.

[2] Derry S, Lloyd R, Moore RA, et al. Topical capsaicin for chronic neuropathic pain in adults. Cochrane Database Syst Rev 2009; CD007393.

[3] Hempenstall K, Nurmikko TJ, Johnson RW, et al. Analgesic therapy in postherpetic neuralgia: a quantitative systematic review. PLoS Med 2005; 2: e164.

[4] Jones VM, Moore KA, Peterson DM. Capsaicin 8\% topical patch (Qutenza)--a review of the evidence. J Pain Palliat Care Pharmacother 2011; 25: 32-41.

[5] Anand P, Bley K. Topical capsaicin for pain management: therapeutic potential and mechanisms of action of the new highconcentration capsaicin 8\% patch. Br J Anaesth 2011; 107: 490502 . 
[6] Gøransson LG, Mellgren SI, Lindal S, et al. The effect of age and gender on epidermal nerve fiber density. Neurology 2004; 62: 7747.

[8] Truini A, Romaniello A, Galeotti F, et al. Laser evoked potentials for assessing sensory neuropathy in human patients. Neurosci Lett 2004; 361: 25-8.

[9] Pavlaković G, Klinke I, Pavlaković H, et al. Effect of thermode application pressure on thermal threshold detection. Muscle Nerve 2008; 38: 1498-505.

[10] Lauria G, Lombardi R, Camozzi F, et al. Skin biopsy for the diagnosis of peripheral neuropathy. Histopathology 2009; 54: 273-85.

[11] Bassotti G, Battaglia E, Bellone G, et al. Interstitial cells of Cajal, enteric nerves, and glial cells in colonic diverticular disease. J Clin Pathol 2005; 58: 973-7.

[12] Lauria G, Cornblath DR, Johansson O, et al. EFNS guidelines on the use of skin biopsy in the diagnosis of peripheral neuropathy. Eur J Neurol 2005; 12: 747-58.

[13] Campbell LK, Thomas JR, Lamps LW, et al. Protein gene product 9.5 (PGP 9.5) is not a specific marker of neural and nerve sheath tumors: an immunohistochemical study of 95 mesenchymal neoplasms. Mod Pathol 2003; 16: 963-9.

[14] Wöpking S, Scherens A, Haussleiter IS, et al. Significant difference between three observers in the assessment of intraepidermal nerve fiber density in skin biopsy. BMC Neurol 2009; 9: 13 .

[15] Fantini F, Johansson O. Expression of growth-associated protein 43 and nerve growth factor receptor in human skin: a comparative immunohistochemical investigation. J Invest Dermatol 1992; 99: 734-42.

[16] Rage' M, Van Acker N, Facer P, et al. The time course of $\mathrm{CO}_{2}$ laser-evoked responses and skin nerve fibre markers after topical capsaicin in human volunteers. Clin Neurophysiol 2010; 121: 1256-66.

[17] Bursova S, Dubovy P, Vlckova-Moravcova E, et al. Expression of growth-associated protein 43 in the skin nerve fibers of patients with type 2 diabetes mellitus. J Neurol Sci 2012; 315: 60-3.

[18] Fields HL, Rowbotham M, Baron R. Postherpetic neuralgia: irritable nociceptors and deafferentation. Neurobiol Dis 1998; 5: 209-27.

[19] Campbell JN, Meyer RA. Mechanisms of neuropathic pain. Neuron 2006; 52: 77-92.

[20] Nolano M, Simone DA, Wendelschafer-Crabb G, et al. Topical capsaicin in humans: parallel loss of epidermal nerve fibers and pain sensation. Pain 1999; 81: 135-45.

[21] Kennedy WR, Vanhove GF, Lu SP, et al. A randomized, controlled, open-label study of the long-term effects of NGX-4010, a high-concentration capsaicin patch, on epidermal nerve fiber density and sensory function in healthy volunteers. J Pain 2010; 11 : 579-87.

[22] Alawi K, Keeble J. The paradoxical role of the transient receptor potential vanilloid 1 receptor in inflammation. Pharmacol Ther 2010; 125: 181-95.

[23] Bevan S, Szolcsányi J. Sensory neuron-specific actions of capsaicin: mechanisms and applications. Trends Pharmacol Sci 1990; 11:330-3

[24] Chung MK, Gueler AD, Caterina MJ. TRPV1 shows dynamic ionic selectivity during agonist stimulation. Nat Neurosci 2008; 11: 55564.

[25] Gallego-Sandin S, Rodriguez-Garcia A, Alonso MT, et al. The endoplasmic reticulum of dorsal root ganglion neurons contains functional TRPV1 channels. J Biol Chem 2009; 284: 32591-601.

[26] Huang W, Wang H, Galligan JJ, et al. Transient receptor potential vanilloid subtype 1 channel mediated neuropeptide secretion and depressor effects: role of endoplasmic reticulum associated $\mathrm{Ca}^{2+}$ release receptors in rat dorsal root ganglion neurons. J Hypertens 2008; 26: 1966-75.

[27] Chard PS, Bleakman D, Savidge JR, et al. Capsaicin-induced neurotoxicity in cultured dorsal root ganglion neurons: involvement of calcium-activated proteases. Neuroscience 1995; 65: 1099-108.

[28] Han P, McDonald HA, Bianchi BR, et al. Capsaicin causes protein synthesis inhibition and microtubule disassembly through TRPV1 activities both on the plasma membrane and intracellular membranes. Biochem Pharmacol 2007; 73: 1635-45.

[29] Goswami C, Schmidt H, Hucho F. TRPV1 at nerve endings regulates growth cone morphology and movement through cytoskeleton reorganization. FEBS J 2007; 274: 760-72.
[30] Chu C, Levine E, Gear RW, et al. Mitochondrial dependence of nerve growth factor-induced mechanical hyperalgesia. Pain 2011; 152: $1832-7$.

[31] Bley KR, Boorman G, Mohammad B, McKenzie D, Babbar S. The carcinogenic and anti-carcinogenic potential of capsaicin: a comprehensive review. Toxicol Pathol 2012; 40(6): 847-73.

[32] Shimomura Y, Kawada T, Suzuki M. Capsaicin and its analogs inhibit the activity of NADH-coenzyme Q oxidoreductase of the mitochondrial respiratory chain. Arch Biochem Biophys 1989; 270: 573-7.

[33] Athanasiou A, Smith PA, Vakilpour S, et al. Vanilloid receptor agonists and antagonists are mitochondrial inhibitors: how vanilloids cause non-vanilloid receptor mediated cell death Biochem Biophys Res Commun 2007; 354: 50-5.

[34] Dedov VN, Mandadi S, Armati PJ, et al. Capsaicin-induced depolarisation of mitochondria in dorsal root ganglion neurons is enhanced by vanilloid receptors. Neuroscience 2001; 103: 219-26.

[35] Kawakami T, Hikawa N, Kusakabe T, et al. Mechanism of inhibitory action of capsaicin on particulate axoplasmic transportin sensory neurons in culture. J Neurobiol 1993; 5: 545-51.

[36] Szallasi A, Blumberg PM. Vanilloid (capsaicin) receptors and mechanisms. Pharmacol Rev 1999; 51: 159-212.

[37] Tewksbury JJ, Nabhan GP. Seed dispersal. Directed deterrence by capsaicin in chilies. Nature 2001; 412: 403-4.

[38] Jordt SE, Julius D. Molecular basis for species-specific sensitivity to "hot" chili peppers. Cell 2002; 108: 421-30.

[39] Kissin I, Szallasi A. Therapeutic targeting of TRPV1 by resiniferatoxin, from preclinical studies to clinical trials. Curr Top Med Chem 2011; 11:2159-70.

[40] Liu L, Lo Y, Chen I, et al. The responses of rat trigeminal ganglion neurons to capsaicin and two nonpungent vanilloid receptor agonists, olvanil and glyceryl nonamide. J Neurosci 1997; 17: 4101-11.

[41] Ursu D, Knopp K, Beattie RE, et al. Pungency of TRPV1 agonists is directly correlated with kinetics of receptor activation and lipophilicity. Eur J Pharmacol 2010; 641: 114-22.

[42] Dray A. Mechanism of action of capsaicin-like molecules on sensory neurons. Life Sci 1992; 51: 1759-65.

[43] Peppin JF, Majors K, Webster LR, et al. Tolerability of NGX4010 , a capsaicin $8 \%$ patch for peripheral neuropathic pain. J Pain Res 2011; 4: 385-92.

[44] NeurogesX. Inc. website. http://ngsx.client.shareholder.com/releasedetail.cfm?ReleaseID $=621682 \mathrm{http}: / /$ ngsx.client.shareholder.com/ releasedetail.cfm?ReleaseID $=621682$

[45] Lee AJ, King JR, Barrett DA. Percutaneous absorption: a multiple pathway model. J Control Release 1997; 45: 141-15.

[46] Polydefkis M, Hauer P, Sheth S, et al. The time course of epidermal nerve fibre regeneration: studies in normal controls and in people with diabetes, with and without neuropathy. Brain 2004; 127: 1606-15.

[47] Gibbons CH, Wang N, Freeman R. Capsaicin induces degeneration of cutaneous autonomic nerve fibers. Ann Neurol 2010; 68: 88898.

[48] Malmberg AB, Mizisin AP, Calcutt NA, et al. Reduced heat sensitivity and epidermal nerve fiber immunostaining following single applications of a high concentration capsaicin patch. Pain 2004; 111: 360-7.

[49] Menczel E, Maibach HI. In: vitro human percutaneous penetration of benzyl alcohol and testosterone: epidermal-dermal retention. J Invest Dermatol 1970; 54: 386-94.

[50] Kimura ET, Darby TD, Krause RA, et al. Parenteral toxicity studies with benzyl alcohol. Toxicol Appl Pharm 1971; 18: 60-8.

[51] DeLand FH. Intrathecal toxicity studies with benzyl alcohol Toxicol Appl Pharmacol 1973; 25: 153-6.

[52] Chang YS, Lin CF, Wu CL, et al. Mechanisms underlying benzyl alcohol cytotoxicity (triamcinolone acetonide preservative) in human retinal pigment epithelial cells. Invest Ophthalmol Vis Sci 2011; 52: 4214-22.

[53] Garnock-Jones KP, Keating GM. Lidocaine 5\% medicated plaster: a review of its use in postherpetic neuralgia. Drugs 2009; 69: 214965.

[54] Krumova EK, Zeller M, Westermann A, et al. Lidocaine patch $(5 \%)$ produces a selective, but incomplete block of $\mathrm{A} \delta$ and $\mathrm{C}$ fibers. Pain 2012; 153: 273-80.

[55] Wehrfritz A, Namer B, Ihmsen H, et al. Differential effects on sensory functions and measures of epidermal nerve fiber density 
after application of a lidocaine patch (5\%) on healthy human skin. Eur J Pain 2011; 15: 907-12.

[56] Campbell BJ, Rowbotham M, Davies PS, et al. Systemic absorption of topical lidocaine in normal volunteers, patients with post-herpetic neuralgia, and patients with acute herpes zoster. J Pharm Sci 2002; 91: 1343-50.

[57] Rolsted K, Benfeldt E, Kissmeyer AM, et al. Cutaneous in vivo metabolism of topical lidocaine formulation in human skin. Skin Pharmacol Physiol 2009; 22: 124-7.

[58] Meng QT, Xia ZY, Liu J, et al. Local anesthetic inhibits hyperpolarization-activated cationic currents. Mol Pharmacol 2011; 79: 866-73.

[59] Leffler A, Fischer MJ, Rehner D, et al. The vanilloid receptor TRPV1 is activated and sensitized by local anesthetics in rodent sensory neurons. J Clin Invest 2008; 118: 763-76.

[60] Johnson ME, Saenz JA, DaSilva AD, et al. Effect of local anesthetic on neuronal cytoplasmic calcium and plasma membrane lysis (necrosis) in a cell culture model. Anesthesiology 2002; 97: 1466-76.

[61] Johnson ME, Uhl CB, Spittler KH, et al. Mitochondrial injury and caspase activation by the local anesthetic lidocaine. Anesthesiology 2004; 101: 1184-94.

[62] Onizuka S, Yonaha T, Tamura R, et al. Lidocaine depolarizes the mitochondrial membrane potential by intracellular alkalization in rat dorsal root ganglion neurons. J Anesth 2011; 25: 229-39.

[63] Endo pharmaceuticals citizen's petition, FDA Docket No. FDA2006-P-0346-0006.

[64] Burakgazi AZ, Messersmith W, Vaidya D, et al. Longitudinal assessment of oxaliplatin-induced neuropathy. Neurology 2011; 77: 980-6.

[65] Koskinen MJ, Kautio AL, Haanpää ML, et al. Intraepidermal nerve fibre density in cancer patients receiving adjuvant chemotherapy. Anticancer Res 2011; 31: 4413-6.

[66] Brannagan TH 3rd, Hays AP, Chin SS, et al. Small-fiber neuropathy/neuronopathy associated with celiac disease: skin biopsy findings. Arch Neurol 2005; 62: 1574-8.

[67] Oaklander AL, Rissmiller JG, Gelman LB, et al. Evidence of focal small-fiber axonal degeneration in complex regional pain syndrome-I (reflex sympathetic dystrophy). Pain 2006; 120: 23543.

[68] Boucek P, Havrdova T, Voska L, et al. Severe depletion of intraepidermal nerve fibers in skin biopsies of pancreas transplant recipients. Transplant Proc 2005; 37: 3574-5.

[69] Boucek P, Havrdova T, Voska L, et al. Epidermal innervation in type 1 diabetic patients: a 2.5 -year prospective study after simultaneous pancreas/kidney transplantation. Diabetes Care 2008; 31:1611-2.

[70] Levy DM, Terenghi G, Gu XH, et al. Immunohistochemical measurements of nerves and neuropeptides in diabetic skin: relationship to tests of neurological function. Diabetologia 1992; 35: 889-97.

[71] Properzi G, Francavilla S, Poccia G, et al. Early increase precedes a depletion of VIP and PGP-9.5 in the skin of insulin-dependent diabetics--correlation between quantitative immunohistochemistry and clinical assessment of peripheral neuropathy. J Pathol 1993; 169: 269-77.

[72] Kennedy WR, Wendelschafer-Crabb G, Johnson T. Quantitation of epidermal nerves in diabetic neuropathy. Neurology 1996; 47: 1042-8.

[73] Hahn K, Triolo A, Hauer P, et al. Impaired reinnervation in HIV infection following experimental denervation. Neurology 2007; 68: 1251-6.

[74] Pittenger GL, Ray M, Burcus NI, et al. Intraepidermal nerve fibers are indicators of small-fiber neuropathy in both diabetic and nondiabetic patients. Diabetes Care 2004; 27: 1974-9.

[75] Wilder-Smith EP, Ong WY, Guo Y, et al. Epidermal transient receptor potential vanilloid 1 in idiopathic small nerve fibre disease, diabetic neuropathy and healthy human subjects. Histopathology 2007; 51: 674-80.

[76] Lauria G, McArthur JC, Hauer PE, et al. Neuropathological alterations in diabetic truncal neuropathy: evaluation by skin biopsy. J Neurol Neurosurg Psychiatry 1998; 65: 762-6.

[77] Scott LJ, Griffin JW, Luciano C, et al. Quantitative analysis of epidermal innervation in Fabry disease. Neurology 1999; 52: 124954.
[78] Schiffmann R, Hauer P, Freeman B, et al. Enzyme replacement therapy and intraepidermal innervation density in Fabry disease. Muscle Nerve 2006; 34: 53-6.

[79] Liguori R, Di Stasi V, Bugiardini E, et al. Small fiber neuropathy in female patients with Fabry disease. Muscle Nerve 2010; 41: 40912.

[80] Üçeyler N, He L, Schönfeld D, et al. Small fibers in Fabry disease: baseline and follow-up data under enzyme replacement therapy. $\mathrm{J}$ Peripher Nerv Syst 2011; 16: 304-14.

[81] Pan CL, Tseng TJ, Lin YH, et al. Cutaneous innervation in Guillain-Barré syndrome: pathology and clinical correlations. Brain 2003; 126: 386-97.

[82] Ruts L, van Doorn PA, Lombardi R, et al. Unmyelinated and myelinated skin nerve damage in Guillain-Barré syndrome: correlation with pain and recovery. Pain 2012; 153: 399-409.

[83] Polydefkis M, Yiannoutsos CT, Cohen BA, et al. Reduced intraepidermal nerve fiber density in HIV-associated sensory neuropathy. Neurology 2002; 58: 115-9.

[84] Zhou L, Kitch DW, Evans SR, et al. Correlates of epidermal nerve fiber densities in HIV-associated distal sensory polyneuropathy. Neurology 2007; 68: 2113-9.

[85] Obermann M, Katsarava Z, Esser S, et al. Correlation of epidermal nerve fiber density with pain-related evoked potentials in HIV neuropathy. Pain 2008; 138: 79-86.

[86] Karanth SS, Springall DR, Lucas S, et al. Changes in nerves and neuropeptides in skin from 100 leprosy patients investigated by immunocytochemistry. J Pathol 1989; 157: 15-26.

[87] Facer P, Mathur R, Pandya SS, et al. Correlation of quantitative tests of nerve and target organ dysfunction with skin immunohistology in leprosy. Brain 1998; 121: 2239-47.

[88] Tseng MT, Hsieh SC, Shun CT, et al. Skin denervation and cutaneous vasculitis in systemic lupus erythematosus. Brain. 2006; 129: 977-85.

[89] Gøransson LG, Tjensvoll AB, Herigstad A, et al. Small-diameter nerve fiber neuropathy in systemic lupus erythematosus. Arch Neurol 2006; 63: 401-4.

[90] Pittenger GL, Mehrabyan A, Simmons K, et al. Small fiber neuropathy is associated with the metabolic syndrome. Metab Syndr Relat Disord 2005; 3: 113-21.

[91] Springall DR, Karanth SS, Kirkham N, et al. Symptoms of notalgia paresthetica may be explained by increased dermal innervation. J Invest Dermatol 1991; 97: 555-61.

[92] Inaloz HS, Kirtak N, Erguven HG, et al. Notalgia paresthetica with a significant increase in the number of intradermal nerves. J Dermatol 2002; 29: 739-43.

[93] Nolano M, Provitera V, Estraneo A, et al. Sensory deficit in Parkinson's disease: evidence of a cutaneous denervation. Brain. 2008; 131: 1903-11.

[94] Schüning J, Scherens A, Haussleiter IS, et al. Sensory changes and loss of intraepidermal nerve fibers in painful unilateral nerve injury. Clin J Pain 2009; 25: 683-90.

[95] Rowbotham MC, Yosipovitch G, Connolly MK, et al. Cutaneous innervation density in the allodynic form of postherpetic neuralgia. Neurobiol Dis 1996; 3: 205-14.

[96] Oaklander AL, Romans K, Horasek S, et al. Unilateral postherpetic neuralgia is associated with bilateral sensory neuron damage. Ann Neurol 1998; 44: 789-95.

[97] Oaklander AL. The density of remaining nerve endings in human skin with and without postherpetic neuralgia after shingles. Pain 2001; 92: 139-45.

[98] Petersen KL, Rice FL, Farhadi M, et al. Natural history of cutaneous innervation following herpes zoster. Pain 2010; 150: 7582.

[99] Kalliomäki M, Kieseritzky JV, Schmidt R, et al. Structural and functional differences between neuropathy with and without pain? Exp Neurol 2011; 231: 199-206.

[100] Gopinath P, Wan E, Holdcroft A, et al. Increased capsaicin receptor TRPV1 in skin nerve fibres and related vanilloid receptors TRPV3 and TRPV4 in keratinocytes in human breast pain. BMC Women Health 2005; 5: 2.

[101] Bakkers M, Merkies IS, Lauria G, et al. Intraepidermal nerve fiber density and its application in sarcoidosis. Neurology 2009; 73: 1142-8.

[102] Chai J, Herrmann DN, Stanton M, et al. Painful small-fiber neuropathy in Sjogren syndrome. Neurology 2005; 65: 925-7. 
[103] Gøransson LG, Brun JG, Harboe E, et al. Intraepidermal nerve fiber densities in chronic inflammatory autoimmune diseases. Arch Neurol 2006; 63: 1410-3.

[104] Koskinen M, Hietaharju A, Kyläniemi M, et al. A quantitative method for the assessment of intraepidermal nerve fibers in smallfiber neuropathy. J Neurol 2005; 252: 789-94.

[105] De Sousa EA, Hays AP, Chin RL, et al. Characteristics of patients with sensory neuropathy diagnosed with abnormal small nerve fibres on skin biopsy. J Neurol Neurosurg Psychiatry 2006; 77 : 983-5.

[106] Lauria G, Morbin M, Lombardi R, et al. Expression of capsaicin receptor immunoreactivity in human peripheral nervous system and in painful neuropathies. J Peripher Nerv Syst 2006; 11: 262-71.

[107] Bohm-Starke N, Hilliges M, Falconer C, et al. Increased intraepithelial innervation in women with vulvar vestibulitis syndrome. Gynecol Obstet Invest 1998; 46: 256-60.

[108] Tympanidis P, Terenghi G, Dowd P. Increased innervation of the vulval vestibule in patients with vulvodynia. Br J Dermatol 2003; 148: 1021-7.

[109] Tympanidis P, Casula MA, Yiangou Y, et al. Increased vanilloid receptor VR1 innervation in vulvodynia. Eur J Pain 2004; 8: 12933.

[110] Tobias J, Smith G, Bley K, et al. The effect of three topical capsaicin liquid formulations on epidermal nerve fiber density and sensory function in healthy volunteers. Poster presentation at the 7 th Congress of the European Federation of IASP ${ }^{\circledR}$ Chapters $\left(\right.$ EFIC $\left.^{\circledR}\right)$; Hamburg, Germany: 21-24 September, 2011.

[111] Tobias J, Webster L, Smiith G, et al. Effect of application duration of a new topical capsaicin liquid on epidermal nerve fiber density and sensory function. Poster presentation at the 7 th Congress of the European Federation of IASP ${ }^{\circledR}$ Chapters $\left(\mathrm{EFIC}^{\circledR}\right)$; Hamburg, Germany: 21-24 September, 2011.

[112] Ebenezer GJ, O'Donnell R, Hauer P, et al. Impaired neurovascular repair in subjects with diabetes following experimental intracutaneous axotomy. Brain 2011; 134: 1853-63.

[113] Simone DA, Nolano M, Johnson T, et al. Intradermal injection of capsaicin in humans produces degeneration and subsequent reinnervation of epidermal nerve fibers: correlation with sensory function. J Neurosci 1998; 18: 8947-59.

[114] Khalili N, Wendelschafer-Crabb G, Kennedy WR, et al. Influence of thermode size for detecting heat pain dysfunction in a capsaicin model of epidermal nerve fiber loss. Pain. 2001; 91: 241-50.

[115] Reilly DM, Ferdinando D, Johnston C, et al. The epidermal nerve fibre network: characterization of nerve fibres in human skin by confocal microscopy and assessment of racial variations. $\mathrm{Br} \mathrm{J}$ Dermatol 1997; 137: 163-70.

(C) Keith Bley; Licensee Bentham Open.

This is an open access article licensed under the terms of the Creative Commons Attribution Non-Commercial License (http://creativecommons.org/licenses/by-nc/3.0/) which permits unrestricted, non-commercial use, distribution and reproduction in any medium, provided the work is properly cited. 